\title{
PERENCANAAN MASTERPLAN TEKNOLOGI INFORMASI PADA PEMERINTAHAN DESA BERBASIS E-GOVERNMENT
}

\author{
I Gede Juliana Eka Putra1 ${ }^{1}$, Made Adi Paramartha Putra' ${ }^{2}$ I Ketut Agus Juliana ${ }^{3}$ \\ 1,2 Prodi Teknik Infromatika STMIK Primakara, Jalan Tukad Badung no 135 Renon Denpasar Indonesia \\ 3 Prodi Sistem Informasi STMIK Primakara, Jalan Tukad Badung no 135 Renon Denpasar Indonesia
}

\begin{abstract}
Abstrak
E-Government merupakan salah satu langkah pemerintah untuk dapat memberikan pelayanan kepada masyarakat dengan memanfaatkan teknologi khususnya Website. Salah satunya adalah penerpan e-Government pada pemerintahan yang paling kecil yaitu Desa. Desa sebagai ujung tombak pemerintahan di Indonesia sudah seharusnya menggunakan e-Government sebagai pelayanan kepada masyarakat sehingga dapat mudah diakses dan cepat. Namun dari hasil penelitian terakhir yang dilakukan penerapan e-Government masih belum maksimal pada tingkat pemerinahan Desa. Penelitian ini mengambil studi kasus di Desa Batungsel. Tabanan yang merupakan salah satu desa yang belum menerapkan e-Government untuk sistem pemerintahannya. Banyak faktor yang menyebabkan mulai dari anggaran hingga Sumber Daya Manusia yang belum memadai. Penelitian ini menggunakan metode deskriptif kuantitatif yaitu dengan menggunakan metode-metode yang sistematis untuk mendapatkan untuk dilakukan analisis kemudian dijadikan patokan pengembangan e-Government. Dari Analisis yang dilakukan Desa Batungsel masih belum memadai dari segi infratruktur, Sumber Daya Manusia dan juga anggaran. Pada masterplan e-Government yang akan direncanakan diberikan skala prioritas pembangunan sehingga sesuai dengan kebutuhan desa dan bermanfaat baik bagi pemerintah ataupun masyarakat Desa Batungsel.
\end{abstract}

Kata Kunci:

Master Plan, $e$ -

Government, analisis

SWOT

\begin{abstract}
E-Government is one step the government can provide services to the community by utilizing technology, especially the Website. One of them is the implementation of eGovernment in the smallest government, namely Village. Villages as the spearhead of government in Indonesia should use e-Government as a service to the community so that they can be easily accessed and quickly. But from the results of recent research conducted the application of e-Government is still not maximized at the level of village governance. This research took a case study in Batungsel Village is one of the villages that has not implemented e-Government for its government system. Many factors cause starting from the budget to inadequate Human Resources. This research uses a quantitative descriptive method that is by using systematic methods to get the analysis carried out and then used as a benchmark for e-Government development. From the analysis conducted by Batungsel Village, it is still inadequate in terms of infrastructure, Human Resources and also the budget. The e-Government masterplan that will be planned is given a scale of development priorities so that it is in accordance with the needs of the village and is beneficial for both the government and the people of Batungsel Village.
\end{abstract}

Keywords:

Master Plan, $e$ -

Government, SWOT

analysis

\section{PENDAHULUAN}

Perkembangan teknologi yang semakin pesat membuat semua sendi kehidupan menggunakan teknologi. Salah satunya adalah sistem pemerintah, yang mulai beradaptasi dengan teknologi untuk 
palayanan kepada masyarakat lebih efektif dan juga efisien. Dalam pembangunan kawasan pedesaan terdapat beberapa isu strategis seperti rendahnya tingkat kesahteraan dan kualitas hidup masyarakat, belum memadainya sarana dan prasarana baik yang bersifat fisik maupun non fisik, serta kurang berdayanya masayarakat yang diakibatkan oleh factor ekonomi dan non ekonomi (Andari \& Ella, 2019). Teknologi Informasi dan Komunikasi (TIK) dapat meningkatkan kecepatan penyampaian informasi, efisiensi, jangkauan global dan transparansi. Salah satu upaya untuk mewujudkan pemerintahan yang good corporate governance (GCG) pada era otonomi daerah adalah menggunakan teknologi informasi dan komunikasi atau yang popular disebut dengan e-Government (Rudy \& Prasetia, 2018).

Penerapan teknologi pada sistem pemerintahan dikenal sebagai E-Government secara bertahap digunakan oleh negara-negara di dunia untuk memberikan pelayanan berupa pusat informasi dengan segala layanan publik. Di Indonesia penerapan E-Government ditandai dengan Inpres No 3 tahun 2003 tentang kebijakan dan strategi nasional pengembangan e-Government, disebutkan bahwa setiap Pemerintah Daerah (Pemda) dapat mengambil langkah-langkah yang diperlukan sesuai dengan tugas pokok, fungsi, dan kewenangannya untuk melaksanakan pengembangan pelayanan pemerintahan berbasis Teknologi Informasi dan Komunikasi (TIK) secara nasional(Indonesia, 2004). E-Government adalah sebuah reformasi atau paradigma baru dari pelaksanaan pemerintah yang mengacu kepada keterbukaan informasi publik yang memberikan tanggung jawab kepada pemerintah untuk memberikan informasi tentang kegiatan-kegiatan pemerintah yang berlangsung (Risnandar, 2014). Menurut definisi World Bank (2004), e-Government adalah penggunaan teknologi informasi oleh badan-badan yang memiliki kemampuan untuk mewujudkan hubungan warga negara, pelaku bisnis dan lembaga pemerintah. Sedangkan menurut EZ Giv, pengertian e-Government adalah penyederhanaan praktek pemerintahan dengan menggunakan teknologi informasi dan komunikasi. Jadi jelaslah bahwa e-Government bertujuan untuk efisiensi karena bersifat penyederhanaan dalam praktek pemerintahan (Novi Prisma Yunita, 2018).

E-Government menawarkan pelayanan publik bisa di akses secara 24jam, kapan pun, dan dari mana pun pengguna berada. E-Government juga memungkinkan pelayanan publik tidak dilakukan secara face to face sehingga pelayanan menjadi lebih efesien (Fatmawati, Irviani et al., 2016). Pelayanan yang dikenal dengan sebutan e-Government diharapkan mampu mendongkrak kualitas Pemerintah kepada masyarakat karena dapat menghemat waktu layanan, percepatan proses, menyederhanakan birokrasi, serta adanya transparansi terhadap proses, biaya, maupun waktu pelayanan. Oleh karena itu, peningkatan kualitas pelayanan merupakan prasyarat terwujudnya Good Governance of Government. Salah satu tujuan implementasi e-government adalah agar lembaga pemerintah mampu menyediakan pelayanan publik yang lebih baik(Nugraha, 2018). Dalam penerapannya di Indonesia, dari tahun 2003 sampai dengan tahun 2018 sebanyak 483 pemerintah Kabupaten/kota sudah menerapkan e-government atau sejumlah 88\% dari total keseluruhan Kabupaten/kota sedangkan 12\% lainnya tidak dapat diakses sampai dengan tidak memiliki egovernment, selain itu peringkat Indonesia masih pada-109 diantara seluruh negara di Indonesia. Mendukung penerapan e-government di Indonesia pemerintah rutin mengadakan E- Government award yang diberikan kepada daerah yang berhasil mengembangkan serta menerapkan e-government di daerahnya. Pada umumnya Implementasi e-Government lebih banyak diterapkan pada wilayah perkotaan dikarenakan sebagian besar pedesaan masih memiliki kendala minimnya infrastruktur TIK serta kurangnya sumber daya manusia yang memiliki kemampuan dibidang TIK (Noor Asyikin et al., 2015).

Dalam menunjang penerapan e-Government di daerah tentunya harus dimulai dari pemerintahan paling kecil yaitu Desa. Desa merupakan bagian terkecil dari sistem pemerintahan administratif di Indonesia, yang dituntut untuk terus mengikuti perkembangan teknologi dan meningkatkan kemampuannya dalam mengelola data administrasi kependudukan desa (Asyikin et al., 2016). Pemerintah Desa adalah lembaga pemerintah yang bertugas mengelola wilayah tingkat desa. Lembaga ini diatur melalui Peraturan Pemerintah No. 72 Tahun 2005 tentang pemerintah desa yang diterbitkan untuk melaksanakan ketentuan pasal 216 ayat (1) Undang - Undang Nomor 32 Tahun 2004 tentang pemerintah daerah (Polii et al., 2017). Kemandirian suatu desa dapat dilihat dari majunya infrastrtuktur desa, bidang social, ekonomi, serta budayanya (Otong Husni Taufiq, Dini Yuliani, 2019). Menurut UU nomor 6 tahun 2014 tentang Desa, Pembangunan Desa adalah upaya peningkatan kualitas hidup dan kehidupan untuk sebesar-besarnya kesejahteraan masyarakat desa (Mayowan, 2016).

Desa Batungsel merupakan salah satu desa yang terletak di administratif Kecamatan Pupuan, Kabupaten Tabanan. Namun Desa Batungsel menjadi salah satu desa yang belum secara maksinal menerapkan E-Government dalam memberikan pelayanan kepada masyarakat yang dikarenakan belum adanya perencanan masterplan teknologi informasi pemerintahan desa yang berbasis e-government. Dengan adanya perencanan masterplan terkait teknologi informasi ini diharapkan pelayanan kepada masyarakat lebih efektif dan efisien. 


\section{METODE}

Metode penelitian yang digunakan adalah deskriptif kuantitatif yaitu menggunakan metodemetode sistematis untuk membangun e-government serta melakukan analisis terhadap sistem yang sudah ada dan kebutuhan dari desa sendiri. Dalam pengembangan e-Government terdapat tahapantahapan yang digunakan yaitu :

(1) Analisis Organisasi dan Kondisi saat ini Pada tahap ini analisis dilakukan untuk mengetahui organisasi khususnya pemerintah desa, khususnya seperti visi, misi, profil, tujuan dan juga strategi sehingga dapat dikertahui fokus pengembangan e-Government. Sehingga pengembangan eGovernment mampu dimaksimalkan sesuai dengan potensi yang ada saat ini. Selain itu dilakukannya analisis terhadap kondisi saat ini memberikan hasil pengembangan yang sesuai dengan kebutuhan masyarakat dan pemerintah sehingga menghasilkan e-Government yang bermanfaat penuh bagi pelayanan kepada masyarakat.

(2) Perencanaan Strategi Teknologi Informasi. Setelah melakukan analisis pada organisasi dan kondisi saat ini, kemudian mulai direncanakan strategi pengembangan teknologi informasi yang nantinya akan diimplementasikan.

(3) Analisis kondisi exiting, analisis kondisi exiting dilakukan untuk mengetahui implementasi eGovernment secara keseluruhan, yang meliputi aspek sumber daya manusia (SDM), sistem informasi, serta infrastruktur teknis dengan menggunakan analisis SWOT. Analisa SWOT untuk mengetahui dan menganalisis keadaan ekternal seperti peluang dan ancaman, serta keadaan internal seperti kekuatan dan kelemahan yang dimiliki(Wiguna \& Saintika, 2018).

(4) Mendefinisikan kebutuhan TIK, infrastruktur dan e-Government. Setelah mengetahui keperluan secara internal, kemudian dilakukan definisi terhadap kebutuhan baik SDM, infratruktur maupun sistem tata kelola sehingga nantinya akan dijalankan sesuai dengan kebutuhan yang ada.

(5) Mendefinisikan program kerja. Program kerja yang nantinya dihasilkan dapat dijadikan sebagai acuan dalam operasional sehari-hari dan juga maintance dari e-government supaya terus dapat ditingkatkan untuk melayani masyarakat.

\section{HASIL DAN PEMBAHASAN}

\section{A. Analisis Organisasi dan Kondisi saat ini pada Desa Batungsel}

Kegiatan pertama yang dilakukan menghasilkan beberapa analisis sebagai berikut :

\section{a. Profil Desa Batungsel}

Desa Batungsel merupakan salah satu desa di daerah administratif Kecamatan Pupuan, Kabupaten Tabanan. Desa dengan wilayah 16,19 km2 menjadikan pertanian sebagai komoditi utama perekonomian desa (Tabanan, 2017), dengan sebagaian besar wilayah merupakan lahan perebunan, khususnya perkebunan kopi. Desa Batungsel memiliki batas wilayah yaitu sebelah utara berbatasan dengan Desa Pujungan, sebelah timur berbatasan dengan Gunung Batukaru, sebelah selatan berbatasan dengan Desa Sanda dan sebelah Barat berbatasan dengan Desa Padangan. Tahun 2019 Desa Batungsel mengadakan pilkades dimana terpilih kepala desa dengan visi misi yaitu :

Visi : Terwujudnya masyarakat Desa Batungsel yang damai, Sejahtera dan Bersatu guna Mewujudkan Pembangunan Sarana Prasarana dan Sumber Daya Manusia yang Berkelanjutan.

Misi :

a. Mewujudkan pemerintah Desa Batungsel yang efektif dan efisien dalam rangka mengoptimalkan pelayanan kepada masyarakat

b. Meningkatkan derajat hidup masyarakat melalui upaya peningkatan pelayanan kesehatan Desa

c. Mengembangkan sektor pertanian dan perkebunan dengan mengedepankan peningkatan kualitas infrastruktur (jalan)

d. Mengembangkan pentingnya peningkatan kualitas sumber daya manusia melalui dukungan terhadap program tentang pendidikan, pelaksanaan kegiatan pelatihan- pelatihan

e. Meningkatkan kegiatan lembaga- lembaga kemasyarakatan yang ada di Desa

\section{b. Kondisi Desa Batungsel}

Kondisi pemerintahan Desa Batungsel secara umum dari sistem operasionalnya sebagian besar menggunakan sistem manual, seperti pencatatan dan juga berkas-berkas mengenai data Desa, namun dari tahun ke tahun sudah mulai beralih menggunakan teknologi. Sistem kelembagaaan Batungsel tidak memiliki bidang khusus yang mencangkup pemanfaatan teknologi atau e-Government sehingga 
perkembangan pemanfaatan teknologi di sistem pemerintahan desa masih kurang. Selain pemanfaatan teknologi Sumber Daya Manusia masih kurang, ini dilihat dari usia produktif desa belum memiliki pengetahuan tentang teknologi dan pemanfaatannya, pegawai desa sebagaian besar belum fasih menggunakan teknologi khususnya sistem informasi yaitu website. Hasil dari analisis yang dilakukan anggaran Desa Batungsel hanya 2,2\% dari total seluruh anggaran untuk teknologi dan bisa berubah karena adanya pandemi covid-19. Dari sisi ekonomi sebagaian masyarakat Desa Batungsel bermata pencaharian sebagai petani, dengan produksi pokok adalah kopi. Dimana salah satu yang terkenal adalah Kopi Mutiara yang merupakan hasil olahan kopi dari petani di Desa Batungsel. Dari sisi infrastruktur di Desa Batungsel sendiri kurang memadai untuk pemanfaatan teknologi sera pengembangan e-government, fasilitas seperti internet hanya terdapat di kantor desa dan digunakan hanya untuk kepentingan pemerintahan.

\section{B. Perencanaan Strategi Teknologi Informasi}

Perencanaan strategi teknologi informasi mencangkup visi, misi, prioritas pengembangan dan juga strategi pengembangan TIK yang disusun, diselaraskan dan diharmonisasikan dengan visi dan misi pemerintah Desa Batungsel saat ini, dimana dengan penyusunan ini dapat menjadi pondasi dalam pengembangan e-government di Desa Batungsel.

(1) Prioritas Pengembangan e-Government: Penerapan e-Government di beberapa lembaga mengacu pada tahapan pengembangan e-Government secara nasional dan penerapannya disesuaikan dengan kondisi yang ada di setiap lembaga pemerintah, yang mencangkup:

a. Prioritas layanan elektronik yang akan diberikan

b. Kondisi infrastruktur informasi yang dimiliki

c. Kondisi kegiatan layanan saat ini

d. Kondisi anggaran dan sumber daya manusia yang dimiliki

Oleh karena itu dengan anggaran desa mengenai bidang teknologi yang kecil dari total seluruh

APBDes dan kurangnya Sumber Daya Manusia yang memadai, maka pengembangan eGovernment di fokuskan pada tahap persiapan dan juga pematangan dengan mengkhusus pada sektor birokrasi, pertanian dan juga pelatihan Sumber Daya Manusia.

(2) Strategi Pengembangan e-Government: Strategi pengembangan e-Government mencangkup tujuan dari suatu organisasi, dalam penyusunan strategi diperlukan identifikasi tujuan institusi kemudian identifikasi tujuan pimpinan sehingga dapat merumuskan tujuan dari implementasi eGovernment. Keseluruhan proses dalam pengembangan e-Government dapat dijabarkan sebagai berikut :
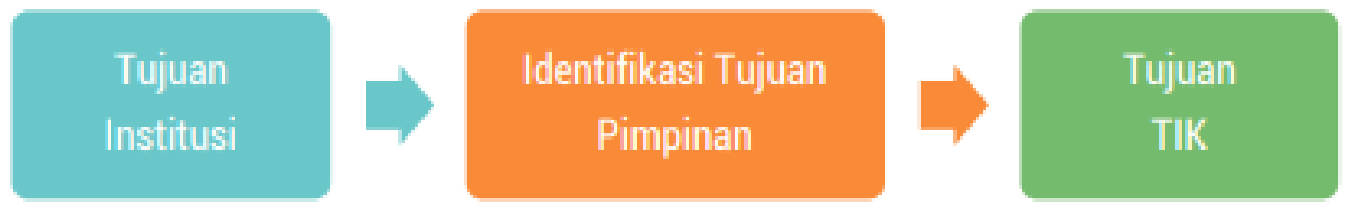

Gambar 1. Diagram alur proses pengembangan e-Government

Tujuan dari implementasi e- government di Desa Batungsel dapat dijabarkan sebagai berikut:

a. Meningkatkan mutu layanan pemerintah desa melalui pemanfaatan TIK dalam proses birokrasi/penyelenggaraan pemerintah Desa

b. Terbentuknya pemerintahan yang efektif, efisien, bersih, dan juga transparan

c. Perbaikan sistem manajemen desa dan juga pemanfaatan teknologi dalam bidang pertanian guna mendukung sektor pertanian dan perkebunan baik dalam proses maupun pemasaran

d. Tersedianya Sumber Daya Manusia yang handal dan melek teknologi dan mampu menjawab tuntutan perubahan (globalisasi)

e. Perbaikan sistem organisasi, sistem manajemen dan proses kerja kegiatan kemasyarakatan melalui lembaga- lembaga desa

Selain itu sasaran penerapan juga merupakan hal penting yang untuk implementasi e-Government khususnya di Desa Batungsel, di bawah ini merupakan sasaran penerapan e-Government:

a. Tersedianya layanan pemerintah desa melalui pemanfaatan TIK dalam proses birokrasi/penyelenggaraan pemerintah Desa

b. Tersedianya sistem pemerintahan yang efektif, efisien, bersih, dan juga transparan

c. Tersedianya sistem manajemen desa dan juga pemanfaatan teknologi dalam bidang pertanian

d. Tersedianya Sumber Daya Manusia yang handal 
e. Tersedianya sistem manajemen dan proses kerja kegiatan kemasyarakatan melalui lembagalembaga Desa

Strategi perencanaan e-Government secara detail dapat dilihat pada Tabel berikut.

Tabel 1. Strategi Perencanaan e-Goverenment Desa Batungsel

\begin{tabular}{|c|c|c|}
\hline Sektor/Bidang & Modul & Status \\
\hline \multirow[t]{6}{*}{ Pelayanan } & Kependudukan & Prioritas \\
\hline & Perpajakan dan Retribusi & Prioritas \\
\hline & Pendaftaran dan Perijinan & Prioritas \\
\hline & Bisnis dan Investasi & Prioritas \\
\hline & $\begin{array}{l}\text { Peublikasi Informasi Umum } \\
\text { dan Kepemerintahan }\end{array}$ & Prioritas \\
\hline & Pengaduan Masyarakat & Prioritas \\
\hline Administrasi dan & Surat Elektronik & Prioritas \\
\hline \multirow[t]{4}{*}{ Manajemen } & $\begin{array}{ll}\text { Sistem } & \text { Dokumentasi } \\
\text { Elektronik } & \end{array}$ & Prioritas \\
\hline & Sistem Penunjang Keputusan & Non Prioritas \\
\hline & Kolabrasi dan Investasi & Non Prioritas \\
\hline & $\begin{array}{ll}\text { Manajemen } & \text { Pelaporan } \\
\text { Pemerintah } & \end{array}$ & Prioritas \\
\hline \multirow[t]{3}{*}{ Legislasi } & Sistem Administrasi BPD & Non Prioritas \\
\hline & Sistem Pemilu Desa & Non Prioritas \\
\hline & $\begin{array}{l}\text { Katalog Hukun, Peraturan } \\
\text { dan Perundangan }\end{array}$ & Prioritas \\
\hline \multirow[t]{6}{*}{ Pembangunan } & $\begin{array}{ll}\text { Sistem Infromasi dan Manajemen } \\
\text { Data }\end{array}$ & Prioritas \\
\hline & Pembangunan & \\
\hline & Perencanaan pembangunan desa & Non Prioritas \\
\hline & $\begin{array}{l}\text { Sistem pengadaan barang dan } \\
\text { jasa }\end{array}$ & Prioritas \\
\hline & $\begin{array}{l}\text { Pengelolaan dan monitoring } \\
\text { proyek }\end{array}$ & Non Prioritas \\
\hline & $\begin{array}{l}\text { Sistem informasi dan hasil } \\
\text { pembangunan }\end{array}$ & Non Prioritas \\
\hline \multirow[t]{4}{*}{ Keuangan } & Sistem Anggaran & Prioritas \\
\hline & Sistem Kas & Prioritas \\
\hline & Perbendaharaan & \\
\hline & Sistem Akuntasi Desa & Non Prioritas \\
\hline \multirow[t]{4}{*}{ Kepegawaian } & Pengadaan PNS & Non Prioritas \\
\hline & Sistem absensi & Prioritas \\
\hline & Sistem Penilaian Kinerja PNS & Non Prioritas \\
\hline & $\begin{array}{lll}\text { Sistem } & \text { Pendidikan dan } \\
\text { Latihan } & \end{array}$ & Prioritas \\
\hline \multirow{3}{*}{$\begin{array}{l}\text { Dinas dan Lembaga } \\
\text { (Kepemerintahan) }\end{array}$} & Pengelolaan Barang Daerah & Non Prioritas \\
\hline & Katalog Barang Daerah & Non Prioritas \\
\hline & $\begin{array}{l}\text { Pengelolaan Pendapatan } \\
\text { Desa }\end{array}$ & Non Prioritas \\
\hline \multirow{4}{*}{$\begin{array}{l}\text { Dinas dan Lembaga } \\
\text { (Kewilayahan) }\end{array}$} & Sistem Tata Ruang Desa & Non Prioritas \\
\hline & Potensi Wilayah & Prioritas \\
\hline & Perkebunan dan pertanian & Prioritas \\
\hline & Pariwisata & Non Prioritas \\
\hline \multirow{4}{*}{$\begin{array}{l}\text { Dinas dan Lembaga } \\
\text { (Kemasyarakatan) }\end{array}$} & Kesehatan & Prioritas \\
\hline & Pendidikan & Prioritas \\
\hline & Ketenagakerjaan & Prioritas \\
\hline & Transportasi & Non Prioritas \\
\hline
\end{tabular}

\section{Analisis Kondisi Exiting}

Analisis kondisi exiting dilakukan untuk mengetahui implmentasi e-government secara keseluruhan, 
yang meliputi aspek sumber daya manusia, sistem informasi, serta infrastruktur teknis dengan menggunakan analisis swot (strength, weakness, opportunity, threats). berikut ini merupakan hasil analisis swot pada desa Batungsel :

(1) Strength :

- Desa Batungsel memiliki tanah yang subur dan kondisi

- lingkungan yang memungkinkan untuk perkebunan maupunpertanian yang bisa digunakan untuk menjadi komoditas utama di Desa Batungsel yaitu salah satunya adalah Tanaman Kopi dan tanaman Upakara sebagai komoditas kedua

- Iklim yang mendukung memungkinkan rumput atau bahan pakan ternak dapat tumbuh subur, sehingga budidaya khususnya peternakan menjamur di Desa Batungsel dan dapat dikembangkan

- Belum banyak dikenal secara luas, namun Desa Batungsel memiliki pemandangan alam yang indah, persawahan yang terbentang luas dengan Gunung Batukaru dapat dijadikan destinasi pariwisata

(2) Weakness :

- Kurang merata pendidikan beberapa tahun lalu di Desa Batungsel membuat sebagian besar masyarakat hanya tamatan SD, karena lebih tertarik langsung bekerja di kebun sehingga SDM kurang memadai.

- Infrastruktur yang kurang memadai membuat pelayanan Desa menjadi lebih lambat, selain itu penyimpanan data yang masih manual menyulitkan pengolahan data untuk pembangunan. Termasuk wifi yang hanya ada di kantor desa dan tidak peruntukan untuk publik

- Selain dari segi SDM dan infrastruktur dari segi pemerintahan dimana kelembagaan yang khusus menangani e-Government atau teknologi tidak ada di Pemerintah Desa Batungsel

(3) Opportunities :

- Hasil pertanian baik berupa Kopi ataupun sarana upakara belum dimanfaatkan secara maksimal dalam hal packaging dan juga pemasaran yang masih sebatas dijual ke pengepul sehingga nilai jual bisa ditingkatkan

- Peningkatan penggunaan Teknologi baik untuk Pertanian, Peternakan, Pariwisata dapat membuat efisiensi, pemasaran dan juga daya saing semakin efektif dan juga dapat bermanfaat bagi masyarakat

- Kondisi desa yang masih asli/original dan lingkungan alam yang indah bisa menjadi destinasi wisata, sarana transportasi memadai untuk menuju Desa memudahkan akses wisatawan

(4) Threaths :

- SDM dari luar yang memiliki keterampilan lebih dapat menjadi ancaman serius jika SDM di Desa Batungsel tidak dapat mengolah segala SDA yang ada menjadi peluang

- Infrastruktur yang kurang memadai, tidak adanya kelembagaan khusus yang menangani dan juga Warga Desa yang belum maksimal memanfaatkan teknologi membuat pengembangan EGovernment dan juga teknologi tepat guna untuk masyarakat menjadi semakin lambat

- Warga desa yang tidak mau mengembangakan desa, lebih memilih bekerja di luar membuat generasi penerus untuk pengembangan desa sedikit

Analisis SWOT dapat dirangkum menjadi matriks SWOT sehingga dapat lebih ringkas. Pada matriks SWOT terdapat kolom dan juga tabel yang berisi inti dari analisis yang dilakukan beserta pada kolom yang terletak di tengah berisi rencana yang akan dilakukan untuk mengoptimalkan hasil analissi SWOT. Matriks SWOT pengembangan e-Government Desa Batungsel dapat dilihat pada tabel berikut.

Tabel 2. Matrik SWOT Pengembangan e-Government Desa Batungsel

\begin{tabular}{|c|c|c|}
\hline & Opportunity & Threats \\
\hline \multirow{4}{*}{ Matrik SWOT } & 1. Produk yang bernilai tinggi & 1. SDM dari luar desa yang lebih \\
\hline & 2. Penggunaan TTG & terampil \\
\hline & 3. Kondisi desa masih & 2. Infrastruktur yang kalah \\
\hline & asli/original & $\begin{array}{l}\text { 3. SDM dalam desa lebih minat } \\
\text { kerja di luar }\end{array}$ \\
\hline
\end{tabular}




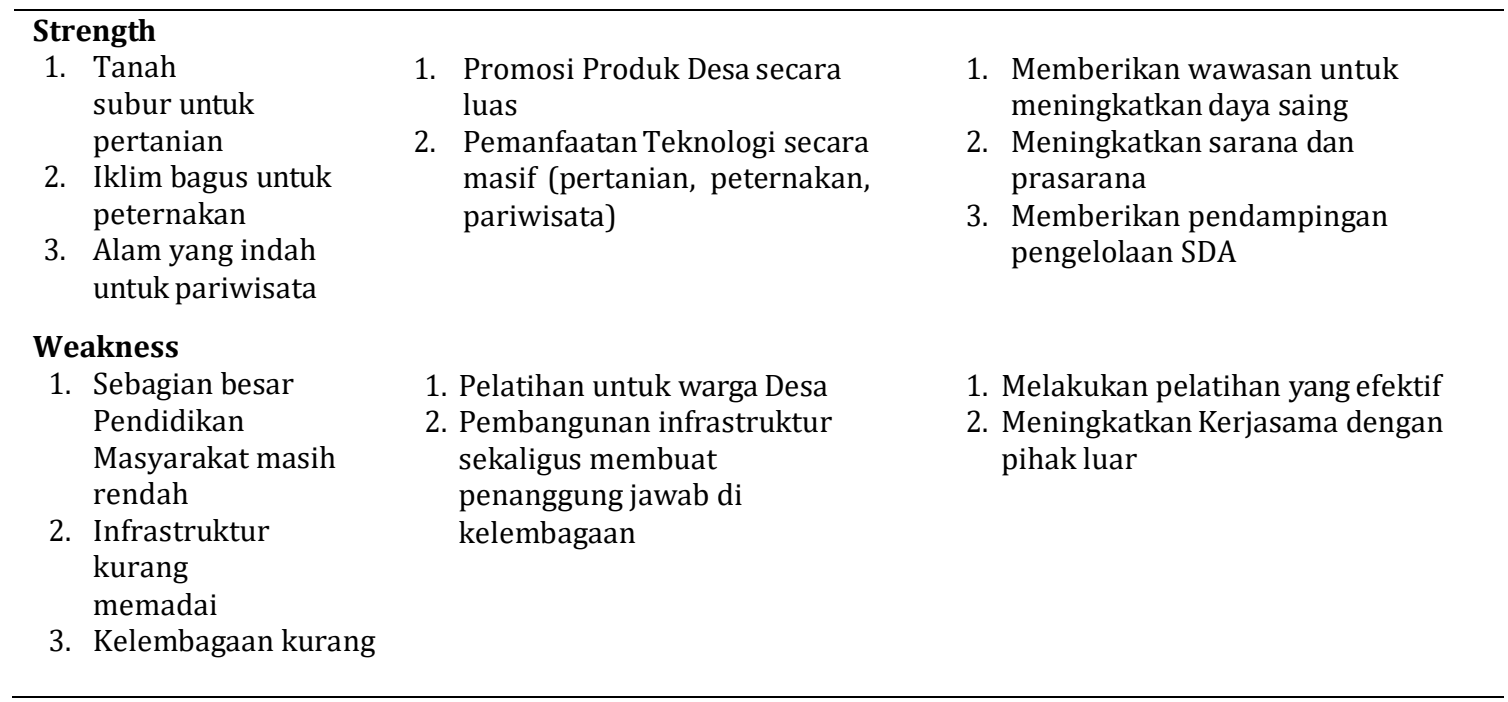

\section{Mendefinisikan Kebutuhan TIK, Infrastruktur dan E-Government}

(1) Rekomendasi Pengembangan Sistem TIK Setelah melakukan beberapa analisis maka rekomendasi terkait dengan konten minimum dari pengembangan e-Government di Desa Bantungsel adalah sebagai berikut:

a. Website Desa

Website merupakan salah satu teknologi informasi yang sudah dikenal di masyarakat luas, selain itu website bisa diakses di semua perangkat. Website saat ini sudah dijadikan media oleh pemerintah daerah dalam menjalankan tujuan $e$ - Government (Warjiyono \& Hellyana, 2018). Website yang dikembangkan berdasarkan strategi yang sudah disusun berdasarkan skala prioritas. Pada website desa terdapat beberapa bagian yang dapat digunakan untuk memaksimalkan potensi masyarakat dan juga efisiensi sistem pemerintahan desa. Bagian tersebut dapat diuraikan sebagai berikut :

- Pelayanan

Pada bagian pelayanan terdapat modul-modul seperti kependudukan, pajak dan juga perijinan yang bisa digunakan oleh pemerintah desa maupun masyarakat, pada bagian ini web desa didesain bisa mengolah data offline dan juga online, sehingga ketika tidak adanya sinyal bagian pelayanan tetap berjalan seperti biasanya sehingga mengoptimalkan pelayanan kepada masyarakat.

- Administrasi dan Manajemen

Administrasi dan Manajemen juga menjadi salah satu bagian yang penting dalam eGovernment sehingga perlu diprioriaskan dalam pengembagnannya. Pada bagian Administrasi dan Manajemen terdapat beberapa modul diantaranya adalah surat elektronik, sistem dokumentasi elektronik dan juga menajemen pelaporan pemerintah. Bagian ini juga merupakan salah satu bagian yang bisa digunakan secara offline oleh pemerintah desa, sehingga tidak menghambat pekerjaan di pemerintah desa.

- $\quad$ Legislasi

Bagian ini mencangkup sistem pemerintahan secara legislatif dan juga produk-produk hukum. Selain itu kelembagaan desa juga bisa diakses melalui bagian ini, rancangan pemilu dan juga calon-calonnya bisa berkampanye dan memberikan inforamasi pada web desa sehingga dapat mensosialisasikan lebih luas.

- Pembangunan

Pada Bagian pembangunan, sistem perencanaan dan juga pemantauan progres pembangunan. Sehingga nantinya semua pembangunan di Desa Batungsel dapat dipantau perkembangannya oleh masyarakat. Pada bagian ini juga terdapat Sistem pengadaan barang yang akan digunakan oleh pemerintah Desa

- Keuangan

Bagian keuangan terdapat modul-modul untuk mengelola tata kelola keuangan di Desa, baik berupa sistem anggaran desa, sistem kas dan perbendaharaan sistem akutansi desa sehingga pemerintah desa menjadi lebih transparan. RAPBDes juga dapat dilihat di bagian ini, menjadikanasyarakat dapat mengawasi dan meminimalisir terjadinya praktek korupsi 
di Desa khususnya anggaran desa.

- Kepegawaian

Sistem kepegawaian merupakan salah satu bagian yang penting, manajeman SDM dan juga manajemen kehadiran pegawai bagian dari modul kepegawaian. Selain itu modul yang penting pada bagian ini adalah sistem pelatihan sumber daya manusia dimana menjadi prioritas dalam pengembangan e-government di Desa Batungsel

- Kepemerintahan

Pada bagian ini terdapat modul pengelolaan barang, katalog barang dan pengelolaan pendapatan Desa. Walaupun bukan prioritas pengembagnan e-government namun bagian ini menjadi pengembangan lanjutan agar pemerintahan dapat berjalan lebih efektif

- Kewilayahan

Pada bagian ini terdapat 2 hal yang menjadi prioritas pengembangan yaitu modul potensi wilayah dan juga modul perebunan dan pertanian yang menjadi komuditi Utama masyarakat di Desa Batungsel

- Kemasyarakatan

Kesehatan, Pendidikan, dan Ketenagakerjaan menjadi modul prioritas pada bagian ini selain itu terdapat modul transportasi. Pada bagian ini e-government lebih kepada fasilitas yang diberikan kepada masyarakat.

b. Sosial Media Desa

Sosial Media memberikan peranan yang penting dalam kehidupan pada jaman sekarang, terlebih bagi sistem pemerintahan. Hal tersebut dapat dilihat dari kemampuan sosialisasi di sosial media, baik regulasi ataupun kebijakan yang dikeluarkan oleh pemerintah. Untuk dapat menjangkau lebih mudah masyarakat, dalam pengembangan e-Government Desa Batungsel dibutuhkan juga pengembangan sosial media desa. Tentu dengan tujuan sosialisasi kepada masyarakat, selain itu konten yang informastif dan kemudahan dalam menggunakan sosial media menjadi salah satu peran keberhasilan pengembangan sosial media pada e- Government Desa. Beberapa sosial media yang dapat dimanfaatkan seperti Twitter, Facebook, Instagram dan juga Youtube.

(2) Rancangan Infrastruktur e-Government

a. Aspek Insfrastruktur

Aspek infrastruktur yang disarankan untuk menunjang pengembangan e-Government diDesa Batungsel, beberapa minimal perangkat baik komputer ataupun jaringan harus dipersiapkan untuk dapat menjalankan e-government seperti: hardware minimal Intel Core i-3 ataupun AMD ryzen 3 RAM 2GB Hardisk 500 GB, penambahan acces point untuk perluasan cakupan jaaringan internet.

b. Apek Sumber Daya Manusia

Aspek Sumber Daya Manusia yang dibutuhkan untuk membangun e-Government sekaligus maintenance adalah SDM yang handal dan fasih menggunakan TIK. Aspek ini sangat penting untuk diperhatikan, karena dibutuhkan SDM yang memahami dan menguasai TIK dan dapat bekerja sesuai dengan tugasnya masing- masing, selain itu memahami struktur pemerintahan, memahami proses perekrutan pegawai, memahami proses pengadaan barang, memahami proses akuntasi desa sesuai dengan modul pada strategi pengembangan e-Government. Dalam pembangunan e-Government Desa Batungsel kurang lebih dibutuhkan tenaga kerja yang memahami pengembangan sistem informasi serta infrastruktur jaringan internet.

\section{E. Mendefinisikan Program Kerja}

Penyusunan program kerja atau roadmap e-government di desa batungsel perlu diberikan terger setiap tahunnya sehingga dapat diberikan evauasi terhadap perencanaan. target tiap tahun dapat dijabarkan sebagai berikut :

- Tahun 2020 : Penguatan Struktural Penguatan Strukturan yang dimaksud adalah penguatan organisasi dan infrastruktur yang manjadi penopang utama pengembangan e- Government. Pada pada tahun ini dibentuk bagian khusus dalam sistem pemerintahan desa untuk mengembangkan eGovernment, perekrutan SDM yang diinginkan.

- Tahun 2021 : Implementasi layanan E- Government Pada tahun ini perencanaan pengembangan eGovernment diimplementasikan, organisasi yang sudah terbentuk mulai melakukan kegiatan sesuai dengan strategi pengembangan e-Government

- Tahun 2022 : Integrasi Internal Pemerintah Desa pada sistem e- Government dengan sistem pemerintahan desa dilakukan untuk efektifitas pemerintahan, sehingga segala kegiatan yang 
dilakukan dapat secara digitalisasi baik digunakan oleh pemerintah desa ataupun layanan yang digunakan oleh masyarakat

- Tahun 2023 : Integrasi Eksternal Pemerintah Daerah, Integrasi dengan e-Goverenment pada tingkat daerah menjadi langkah yang dilakukan selajutnya, agar pelayanan semakin baik dan juga mempermudah masyarakat terhadap layanan publik

- Tahun 2024 : Smart Government Setelah integrase menyeluruh dapat dilaksanakan, pengembangan selanjutnya ada pada tahap smart Government dimana pelayanan masyarakat sudah terdigitalisasi dengan baik, selain itu stakeholder terkait juga dapat menikmati layanan teknologi yang diberikan pemerintah desa.

\section{SIMPULAN DAN SARAN}

Berdasarkan hasil penelitian yang dilakukan dalam hal pengembangan e-government dapat disimpulkan beberapa hal seperti berikut :

1. Penelitian menghasilkan analisis terhadap organisasi dan juga kondisi saat ini di Desa Batungsel yang digunakan untuk penyusunan strategi dan menentukan prioritas pengembangan.

2. Masterplan e-Government nantinya dapat digunakan sebagai pedoman dalam pembangunan eGovernment di Desa Batungsel dalam rangka menuju smart government

3. Masterplan e-Government Desa Batungsel dapat digunakan untuk rencana pembangunan di Desa Batungsel

\section{Ucapan Terima Kasih}

Tidak lupa dalam penelitian ini saya ucapkan terima kasih yang sebesar besarnya kepada STMIK Primakara dan Desa Batungsel Kecamatan Pupuan Kabupaten Tabanan-Bali atas dukunganya sehingga penelitian ini dapat berjalan dengan baik.

\section{Daftar Pustaka}

Andari, R. N., \& Ella, S. (2019). Developing A Smart Rural Model for Rural Area Development in Indonesia. Jurnal Borneo Administrator, 15(1), 41-58. https://doi.org/10.24258/jba.v15i1.394

Asyikin, A. N., Fitri, R., \& Nugroho, A. S. B. (2016). Masterplan Teknologi Informasi dan Komunikasi (TIK) Kantor Pemerintah Desa. Poros Teknik, 8(2), 61. https://doi.org/10.31961/porosteknik.v8i2.368

Fatmawati, Irviani, R., Rachman, E. S., Putu, I., Anggie, A., \& Kristina, M. (2016). Tata Kelola Teknologi Informasi Sebagai Implementasi E-Government Pada Kabupaten Pemekaran Untuk Meningkatkan Potensi Daerah. Jurnal Teknologi Informasi, Proseding Senapati, 2015(Senapati), 249-257.

Indonesia, P. R. (2004). Inpres NO 3 tahun 2003 tentang kebijakan dan strategi nasional pengmebangan egoverment (Vol. 2004).

Mayowan, Y. (2016). DI DESA ( Studi Kasus di Kabupaten Lamongan ).

Noor Asyikin, A., Fitri, R., Setiyo Budi, A. N., \& Pengajar Jurusan Teknik Elektro Politeknik Negeri Banjarmasin, S. (2015). Pengukuran Tingkat Kesiapan Kantor Pemerintahan Desa Dalam Penerapan Masterplan Teknologi Informasi Dan Komunikasi (Tik) Perkantoran Desa Menggunakan Kerangka Kerja Cobit 4.1. ISSNPrint) Jurnal POROS TEKNIK, 7(2), 2085-576154.

Novi Prisma Yunita, R. D. A. (2018). Proceeding Sentika 2018. Universitas ATMA Jaya, 329-326.

Nugraha, J. T. (2018). E-Government Dan Pelayanan Publik (Studi Tentang Elemen Sukses Pengembangan E-Government Di Pemerintah Kabupaten Sleman). Jurnal Komunikasi Dan Kajian Media, 2(1), 32-42.

Otong Husni Taufiq, Dini Yuliani, D. H. (2019). Tata Kelola Pemerintah Desa Berbasis E-Government Menuju Good Governance. 06(1), 145-152.

Polii, R. R., Rindengan, Y. D. Y., Karouw, S. D. S., Informatika, T., Teknik, F., Sam, U., \& Manado, R. (2017). Analisa Dan Perancangan Sistem Informasi Desa Berbasis Web Model Government-To-Citizen. Jurnal Teknik Informatika, 12(1). https://doi.org/10.35793/jti.12.1.2017.17789

Risnandar. (2014). Analisis E-Government Dalam Peningkatan Pelayanan Publik Pada Dinas Komunikasi Dan Informatika Provinsi Sulawesi Tengah. Katalogis, 2(7), 192-199.

Rudy, R., \& Prasetia, A. M. (2018). Swot Analysis and Tows Matrix E-Government on Tana Tidung City of Kalimantan Utara. Elinvo (Electronics, Informatics, and Vocational Education), 3(1), 46-51. https://doi.org/10.21831/elinvo.v3i1.19518 
Tabanan, P. K. (2017). Kabupaten Tabanan Dalam Angka 2017. http://library1.nida.ac.th/termpaper6/sd/2554/19755.pdf

Warjiyono, W., \& Hellyana, C. M. (2018). Pengukuran Kualitas Website Pemerintah Desa Jagalempeni Menggunakan Metode Webqual 4.0. Jurnal Teknologi Informasi Dan Ilmu Komputer, 5(2), 139. https://doi.org/10.25126/jtiik.201852666

Wiguna, C., \& Saintika, Y. (2018). Analisis Strength - Weakness Dalam Implementasi Pengembangan IT Masterplan Menggunakan Metode Value chain. Sistemasi, 7(3), 187. https://doi.org/10.32520/stmsi.v7i3.319 